\title{
State of the art preliminary literature review: Sustainability and waste reporting capabilities in management systems
}

\author{
Ari Happonen ${ }^{1 *}$ and Daria Minashkina ${ }^{1}$ \\ ${ }^{1}$ LUT School of Engineering Science, LUT University, Lappeenranta, 53850, Finland.
}

\begin{abstract}
Inspired by previous studies research gap findings and limitations in management system functions to produce sustainabilityrelated reporting authors set a goal to map the current academic literature in the context of waste management systems. The method chosen for the work was a systematic literature review, focusing on the Web of Science and Scopus databases. The authors found a total of 115 unique publications from the selected databases, which were filtered 28 contributing studies. With these studies, this study found that most of the publications are journals and almost half of the work has been published in the last 3 years. Additionally, sustainability and waste management reporting related literature seem to enjoy wide appreciation among the peers, indicated by a high number of references these publications had gathered. As an overall finding, the specific research area of waste management process quantified data reporting seems really young overall and needs additional research with multiple research gaps clearly waiting for follow-up research to pinpoint the specific areas to contribute in the near future. Keywords. Literature review, sustainability reporting, waste management system, systematic mapping study, digitalization.
\end{abstract}

\section{Introduction}

Industry 4.0, new technologies, and digitalization have been major drivers to accelerate changes in the last decade of human history. Globalization has led to unprecedented impacts on the environment and our globally shared natural resources [29]. The degradation of climate conditions, increased amounts of pollutions, and the rising demand for cleaner and renewable-based energy sources have pointed business owners the need to consider new ways to do their business for quite a time already [30]. As a result, companies have recognized a need to start changing the ways they operate. There are already good examples like Unilever, Starbucks, and Nike, with their brand integrated sustainability actions [31].

From a sustainability point of view, supply chains connect us to all assets this study use, making those globally highly important sectors to watch up, study [56], and improve [57, 58 ], as even when our word has gone through a huge burst of digitalization, industry 4.0 actions making industrial impacts to the global supply chains sustainability [32, 33]. Plus, the reduction of a need to possess physical materials (e.g., tapes, DVDs, paper, etc.) has

* Corresponding author: ari.happonen@lut.fi 
limited logistics. But still, the logistics related premises alone form approximately $10 \%$ (300 $\mathrm{CO}_{2}$ megatons) of global logistics and transportation sectors share from $\left(2,800 \mathrm{CO}_{2}\right.$ megatons) total yearly $\mathrm{CO}_{2}$ emissions, which is around 5,5\% of the global total [34]. Based on this data, supply chains highly contribute to our global emissions. Especially now, in Covid-19 pandemic time, when people stay away from physical shops and shop on-line instead, generating demand burst for warehousing, cross-docking, delivery center packets handling, and so on. A perfect setup to ask the question there is what sort of functions warehouse management systems have for sustainability matters reporting and how to decarbonize warehousing activities [35].

The aim of this research was to build on the path of previous research [36-38] painted by indicating research gaps in clearly a large global emission contributing sector. If so obvious area as logistics has shortages of literature in sustainability reporting, what is the case in the waste management sector itself? With the question in mind, this study wanted to map the academic literature situation in the waste management systems side and try to get a basic view of their capability to report sustainability-related matters. Considering the fact, that tools in use in the logistics sector cannot pinpoint and assess the amount of waste and inefficiencies in an explicitly quantified manner in a super competing sector like logistics, what really is the case with the waste management sector, which is handling the end of life of assets what sort of academic literature this study has available for the matter?

\section{Method}

Based on research findings in other research fields, authors decided to start a systematic literature review $[39,40]$ to work on a preliminary mapping of the current academic literature and views on waste management systems to report quantified waste stream data. For this task, a set of keywords was generated based on previous work results on other academics [41-43] and the authors' own experience. The keywords were used to find the academic studies reflecting waste management systems and calculations and/or their reporting capabilities to quantify and show up in numbers the amount of different waste components operations generate, handle and process upon activities the system can see.

For this set research goal, the following keyword combinations were used:

- $\quad$ "waste management system" AND sustain* AND report*

- $\quad$ "waste management system" AND environment* AND report*

- $\quad$ "waste management system" AND recycl* AND report*

- $\quad$ "waste management system" AND calculat* AND report*

With these keywords, two major academic databases (Web of Science and Scopus) were researched. With the databases, following results were found (Table 1).

Table 1. Preliminary results for databases, before filtering rules.

\begin{tabular}{|l|c|c|c|c|c|}
\cline { 2 - 5 } \multicolumn{1}{c|}{} & Web of Science & \multicolumn{3}{c|}{ Scopus } \\
\hline \multicolumn{1}{|c|}{ Keywords } & results & in english & results & in english \\
\hline "waste management system" AND sustain* AND report* & 28 & 28 & 53 & 53 \\
\hline "waste management system" AND environment* AND report* & 48 & 48 & 144 & 141 \\
\hline "waste management system" AND recycl* AND report* & 38 & 149 unique from 190 total & 38 & 86 & 84 \\
\hline "waste management system" AND calculat* AND report* & 9 & 88 unique from 122 total \\
\hline
\end{tabular}


Without filtering, the results were quite generic, including a lot of non-fitting results, and lastly, these software systems related studies started to focus on old things, in a sense how far software and software as a service have been developing lately. To focus on specific content contributing studies, with the databases, following filtering rules were used to get as well contributing results for the research goal as possible:

- not older than from 2010

- written in the English language

- not a report from national institutions, web pages, etc.

By applying the keywords into the selected two major academic databases, the following unique publications were found with different keyword combinations (Table 2).

Table 2. Results from the databases, after adding filtering rules.

\begin{tabular}{|c|c|c|c|c|}
\hline \multirow{2}{*}{ Keywords } & \multicolumn{2}{|c|}{ Results in english \& 2010 - present } & \multirow[b]{2}{*}{ Sums } & \multirow[b]{2}{*}{$\begin{array}{c}\text { Total } \\
\text { Unique }\end{array}$} \\
\hline & WoS (CC) & Scopus & & \\
\hline "waste management system" AND sustain* AND report* & 28 & 44 & 68 & \\
\hline $\begin{array}{l}\text { "waste management system" AND environment* AND } \\
\text { report* }\end{array}$ & 42 & 89 & 131 & \\
\hline "waste management system" AND recycl* AND report* & 29 & 62 & 91 & \\
\hline "waste management system" AND calculat* AND report* & 7 & 9 & 16 & \\
\hline Total sum of findings & 102 & 204 & 306 & \\
\hline
\end{tabular}

In the end, by combining the results to one review set, the given keywords, previously mentioned filtering rules, and the selected databases results combined produced 115 unique results. These academic literature sources were used to proceed to the content review phase of our literature study. The division of the publication channels for the found result is as shown in Figure 1. The publication channel classification is based directly on metadata received from the databases, is as follows:

\begin{tabular}{|c|c|}
\hline PUBLICATION CHANNEL & NUMBER OF PUBLICATION \\
\hline Journal Article & 84 \\
\hline Conference Proceedings & 15 \\
\hline Book Section & 7 \\
\hline Book & 9 \\
\hline
\end{tabular}

Fig. 1. Number of unique publications found for review, from different publication channels.

To follow standard mapping steps, a review of found articles started based on their titles, abstracts, discussion, and conclusion chapters. Finally, the full text was reviewed to select the proper areas of specific studies. The filtering process resulted in 28 unique academic studies with the following distribution between publishing channels (Fgure 2):

\begin{tabular}{|c|c|}
\hline PUBLICATION CHANNEL & NUMBER OF PUBLICATION \\
\hline Journal Article & 18 \\
\hline Conference Proceedings & 5 \\
\hline Book Section & 1 \\
\hline Book & 4 \\
\hline
\end{tabular}

Fig. 2. Found 28 articles publication channels distribution.

Table 3 presents the full list of studies selected for our follow up analysis for the state of academic research within the research area. 
Table 3. Literature sources found for the mapping study.

\begin{tabular}{|c|c|c|c|c|c|c|}
\hline ID/REF & YEAR & TYPE & TITLE & PUBLISHED IN & PAGES & DOI \\
\hline$[1]$ & 2020 & $\begin{array}{l}\text { Journal } \\
\text { Article }\end{array}$ & $\begin{array}{l}\text { A nationwide assesment of litter China's beaches } \\
\text { using citizen science data }\end{array}$ & $\begin{array}{l}\text { Environmental } \\
\text { Pollution }\end{array}$ & $1-10$ & $\begin{array}{l}\text { 10.1016/j.en } \\
\text { vpol.2019.1 } \\
13756\end{array}$ \\
\hline [2] & 2020 & $\begin{array}{l}\text { Journal } \\
\text { Article }\end{array}$ & $\begin{array}{l}\text { A step forward in quantifying the substitutability of } \\
\text { secondary material in wate management life cycle } \\
\text { assessment studies }\end{array}$ & $\begin{array}{c}\text { Waste } \\
\text { Management }\end{array}$ & $331-340$ & $\begin{array}{l}\text { 10.1016/j.wa } \\
\text { smnzuo.202 } \\
0.07 .015\end{array}$ \\
\hline$[3]$ & 2020 & $\begin{array}{l}\text { Journal } \\
\text { Article }\end{array}$ & $\begin{array}{l}\text { Assessment of COVID-19 waste flows during the } \\
\text { emergency state in romania and related public health } \\
\text { and environmental concerns }\end{array}$ & $\begin{array}{l}\text { Int. Journal of } \\
\text { Environmental } \\
\text { Research and } \\
\text { Public Health }\end{array}$ & $1-18$ & $\begin{array}{l}\text { 10.3390/ijer } \\
\text { ph17155439 }\end{array}$ \\
\hline [4] & 2018 & $\begin{array}{l}\text { Journal } \\
\text { Article }\end{array}$ & $\begin{array}{c}\text { Assessment ot Healthcare Waste Generation Rate and } \\
\text { Its Management System in Health Centers of Bench } \\
\text { Maji Zone }\end{array}$ & $\begin{array}{l}\text { Ethiopian journal } \\
\text { of health } \\
\text { scuences }\end{array}$ & $125-134$ & $\begin{array}{l}10.4314, \text { ejh } \\
\text { s.v28i2.4 }\end{array}$ \\
\hline$[5]$ & 2020 & Book & $\begin{array}{l}\text { Assessment of Municipal Solid Waste Management in } \\
\text { Jammu City: Problems, Prospects and Solutions }\end{array}$ & $\begin{array}{l}\text { Lecture Notes in } \\
\text { Civil Engineering }\end{array}$ & 257 & \\
\hline$[6]$ & 2017 & $\begin{array}{l}\text { Journal } \\
\text { Article }\end{array}$ & $\begin{array}{l}\text { Assessment of the municipal sohd waste management } \\
\text { system in Accra, Ghana: A "Wasteaware" benchmark } \\
\text { indicator approach }\end{array}$ & $\begin{array}{l}\text { Waste } \\
\text { Management \& } \\
\text { Research }\end{array}$ & $\begin{array}{l}1149- \\
1168\end{array}$ & $\begin{array}{c}10.1177 / 073 \\
4242 \times 17727 \\
066\end{array}$ \\
\hline [7] & 2011 & $\begin{array}{l}\text { Conference } \\
\text { Proceeding }\end{array}$ & $\begin{array}{l}\text { Charactenzanon of Volume F trash from four recent } \\
\text { STS missions: Weights, catagorization, water content }\end{array}$ & $\begin{array}{l}\text { 41st Int. Conf. on } \\
\text { Environmental } \\
\text { Systems } 2011\end{array}$ & $1-12$ & $\begin{array}{c}10.2514 / 6.2 \\
011-5126\end{array}$ \\
\hline [8] & 2020 & $\begin{array}{l}\text { Journal } \\
\text { Article }\end{array}$ & $\begin{array}{l}\text { Cross-regional mobility of construction and } \\
\text { demolition waste in Australia: An exploratory study }\end{array}$ & $\begin{array}{l}\text { Resources, } \\
\text { Conservation and } \\
\text { Recycling }\end{array}$ & $1-14$ & $\begin{array}{c}\text { 10.1016/j.res } \\
\text { conrec. } 2020 . \\
104710\end{array}$ \\
\hline [9] & 2012 & $\begin{array}{l}\text { Journal } \\
\text { Article }\end{array}$ & $\begin{array}{c}\text { Development of solid waste prediction, } \\
\text { characterization, and modeling tool for the assessment } \\
\text { of manufacturing and service waste management } \\
\text { systems }\end{array}$ & $\begin{array}{l}\text { Journal of Solid } \\
\text { Waste } \\
\text { Technology and } \\
\text { Management }\end{array}$ & $38-87$ & $\begin{array}{l}\text { 10.5276/JS } \\
\text { WTM.2012. } \\
38\end{array}$ \\
\hline$[10]$ & 2010 & $\begin{array}{l}\text { Journal } \\
\text { Article }\end{array}$ & $\begin{array}{l}\text { EASEWASTE-life cycle modeling capabilities for } \\
\text { waste management systems }\end{array}$ & $\begin{array}{l}\text { Int. Journal of Life } \\
\text { Cycle } \\
\text { Assessment }\end{array}$ & $403-416$ & $\begin{array}{c}10.1007 / \mathrm{s} 11 \\
367-010- \\
0156-7\end{array}$ \\
\hline$[11]$ & 2015 & $\begin{array}{l}\text { Journal } \\
\text { Article }\end{array}$ & $\begin{array}{c}\text { Economic-financial analysis of the Italian packaging } \\
\text { waste management system from a local authority's } \\
\text { perspective }\end{array}$ & $\begin{array}{l}\text { Journal of Cleaner } \\
\text { Production }\end{array}$ & $533-541$ & $\begin{array}{l}10.1016 / \mathrm{j} . \mathrm{jcl} \\
\text { epro. } 2014.1 \\
0.069\end{array}$ \\
\hline$[12]$ & 2017 & $\begin{array}{l}\text { Conference } \\
\text { Proceedirgs }\end{array}$ & $\begin{array}{l}\text { Energy balance of waste management systems: A case } \\
\text { study }\end{array}$ & $\begin{array}{l}\text { IEEE Int. Conf. } \\
\text { IEEM } 2017\end{array}$ & $\begin{array}{l}1495- \\
1499\end{array}$ & $\begin{array}{c}10.1109 / 1 \mathrm{E} \\
\mathrm{EM} .2017 .82 \\
90142\end{array}$ \\
\hline [13] & 2013 & $\begin{array}{l}\text { Journal } \\
\text { Article }\end{array}$ & $\begin{array}{c}\text { Establishing biomedical waste management system in } \\
\text { Medical University of India - A successful practical } \\
\text { approach }\end{array}$ & $\begin{array}{l}\text { Clinical } \\
\text { Epidemiology and } \\
\text { Global Health }\end{array}$ & $131-136$ & $\begin{array}{l}\text { 10.1016/j.ce } \\
\text { gh. } 2012.11 \text {. } \\
004\end{array}$ \\
\hline$[14]$ & 2015 & Book & $\begin{array}{l}\text { Evaluation of Current Laboratory Waste } \\
\text { Management: A Step Towards Green Campus at } \\
\text { Amirkabir University of Technology }\end{array}$ & $\begin{array}{l}\text { Book: } \\
\text { Implementing } \\
\text { Campus Greening } \\
\text { Initiatives }\end{array}$ & $215-227$ & $\begin{array}{c}10.1007 / 978 \\
-3-319- \\
11961-8 \_17\end{array}$ \\
\hline$[15]$ & 2020 & $\begin{array}{l}\text { Journal } \\
\text { Article }\end{array}$ & $\begin{array}{l}\text { Evaluation of household food waste generation in } \\
\text { hanoi and policy implications towards SDGs target } \\
12.3\end{array}$ & $\begin{array}{l}\text { Sustainability } \\
\text { (Switzerland) }\end{array}$ & $1-120$ & $\begin{array}{c}10.3390 / \mathrm{su} 1 \\
2166565\end{array}$ \\
\hline$[16]$ & 2014 & $\begin{array}{l}\text { Journal } \\
\text { Article }\end{array}$ & $\begin{array}{l}\text { Evaluation of life cycle inventory data for recycling } \\
\text { systems, Resources, Conservation and Recycling }\end{array}$ & $\begin{array}{l}\text { Resources. } \\
\text { Conservation and } \\
\text { Recycling }\end{array}$ & $30-45$ & $\begin{array}{c}\text { 10.1016/j.res } \\
\text { conrec. } 2014 . \\
03.011\end{array}$ \\
\hline
\end{tabular}




\begin{tabular}{|c|c|c|c|c|c|c|}
\hline$[17]$ & 2011 & Book & $\begin{array}{l}\text { Framework design for eco-industrial park's waste } \\
\text { management system }\end{array}$ & $\begin{array}{l}\text { Advanced } \\
\text { Materials } \\
\text { Research }\end{array}$ & 808 & $\begin{array}{l}10.4028 / \mathrm{ww} \\
\text { w.scientific. } \\
\text { net/AMR.15 } \\
6-157.808\end{array}$ \\
\hline [18] & 2016 & $\begin{array}{l}\text { Journal } \\
\text { Article }\end{array}$ & $\begin{array}{l}\text { Identification of decisive factors for greenhouse gas } \\
\text { emissions in comparative life cycle assessments of } \\
\text { food waste management - an analytical review }\end{array}$ & $\begin{array}{l}\text { Journal Of Cleaner } \\
\text { Production }\end{array}$ & $13-24$ & $\begin{array}{l}10.1016 / \mathrm{j} . \mathrm{jc} \\
1 \text { epro. } 2016 . \\
01.079\end{array}$ \\
\hline [19] & 2014 & $\begin{array}{l}\text { Journal } \\
\text { Article }\end{array}$ & $\begin{array}{l}\text { Identification of key assessment indicators of the zero } \\
\text { waste management systems, Ecological Indicators }\end{array}$ & $\begin{array}{l}\text { Ecological } \\
\text { Indicators }\end{array}$ & $682-693$ & $\begin{array}{l}\text { 10.1016/j.ec } \\
\text { olind.2013.0 } \\
\quad 9.024\end{array}$ \\
\hline$[20]$ & 2019 & $\begin{array}{l}\text { Book } \\
\text { Section }\end{array}$ & $\begin{array}{l}\text { Information System for Decision Support in Waste } \\
\text { Management in the Arctic Region of Russia }\end{array}$ & $\begin{array}{l}\text { Int. Conf. on } \\
\text { Numerical } \\
\text { Analysis and } \\
\text { Applied } \\
\text { Mathematics }\end{array}$ & $1-4$ & $\begin{array}{c}10.1063 / 1.5 \\
114447\end{array}$ \\
\hline [21] & 2020 & $\begin{array}{l}\text { Journal } \\
\text { Article }\end{array}$ & $\begin{array}{l}\text { Interactions of residential waste composition and } \\
\text { collection truck compartment design on GIS route } \\
\text { optimization }\end{array}$ & $\begin{array}{c}\text { Waste } \\
\text { Management }\end{array}$ & $613-623$ & $\begin{array}{l}10.1016 / \text { j.wa } \\
\text { sman.2019.1 } \\
\quad 1.028\end{array}$ \\
\hline$[22]$ & 2020 & $\begin{array}{l}\text { Conference } \\
\text { Proceedings }\end{array}$ & $\begin{array}{l}\text { IoT based university garbage monitoring system for } \\
\text { healthy environment for students }\end{array}$ & $\begin{array}{c}\text { 14th IEEE } \\
\text { International } \\
\text { Conference on } \\
\text { Semantic } \\
\text { Computing }\end{array}$ & $354-358$ & $\begin{array}{l}10.1109 / 1 C \\
\text { SC. } 2020.000 \\
71\end{array}$ \\
\hline$[23]$ & 2012 & Book & $\begin{array}{c}\text { Mathematical Model of Economics of Municipal } \\
\text { Waste Management }\end{array}$ & $\begin{array}{l}\text { Conference: } \\
\text { Mathematica } \\
\text { Methods in } \\
\text { Economics } 2012\end{array}$ & $823-829$ & NA \\
\hline$[24]$ & 2010 & $\begin{array}{l}\text { Conference } \\
\text { Proceedings }\end{array}$ & $\begin{array}{l}\text { Modelling integrated Waste Management System of } \\
\text { the Czech Republic }\end{array}$ & $\begin{array}{l}\text { Int. Conf. on } \\
\text { Systems }\end{array}$ & $510-515$ & NA \\
\hline$[25]$ & 2011 & $\begin{array}{l}\text { Journal } \\
\text { Article }\end{array}$ & $\begin{array}{l}\text { Quantification of greenhouse gas emissions from } \\
\text { waste management processes for municipalities - A } \\
\text { comparative review focusing on Africa }\end{array}$ & $\begin{array}{c}\text { Waste } \\
\text { Management }\end{array}$ & $\begin{array}{c}1585- \\
1596\end{array}$ & $\begin{array}{l}10.1016 / \text { j.wa } \\
\text { sman. } 2011.0 \\
\quad 2.028\end{array}$ \\
\hline$[26]$ & 2019 & $\begin{array}{l}\text { Journal } \\
\text { Article }\end{array}$ & $\begin{array}{l}\text { Shaping and delivering tomorrow's sustainable } \\
\text { municipal solid waste management system: Proposal } \\
\text { for a structured data management infrastructure }\end{array}$ & $\begin{array}{l}\text { Int. Journal of } \\
\text { Environment and } \\
\text { Waste } \\
\text { Management }\end{array}$ & $437-450$ & $\begin{array}{l}\text { 10.1504/1JE } \\
\text { WM.2019.1 } \\
03646\end{array}$ \\
\hline$[27]$ & 2019 & $\begin{array}{l}\text { Conference } \\
\text { Proceedings }\end{array}$ & $\begin{array}{l}\text { Statistical analysis of determinant factors and } \\
\text { framework development for the optimal and } \\
\text { sustainable design of municipal solid waste } \\
\text { management systems in the context of industry } 4.0\end{array}$ & Procedia CRP & $245-250$ & $\begin{array}{l}\text { 10.1016/j.pr } \\
\text { ocir.2019.04 } \\
\quad .182\end{array}$ \\
\hline$[28]$ & 2018 & $\begin{array}{l}\text { Journal } \\
\text { Article }\end{array}$ & $\begin{array}{l}\text { Salas, Sustainability assessment of waste management } \\
\text { system for mexico city (Mexico) - based on analytic } \\
\text { hierarchy process }\end{array}$ & Recycling & $1-18$ & $\begin{array}{l}10.3390 / \text { rec } \\
\text { ycling30300 } \\
\quad 4 S\end{array}$ \\
\hline
\end{tabular}

\section{Results and discussion}

Firstly, this study started with a comparison analysis to see how general keyword defining and areas specific research has been divided between publishing channels. For this study compared the previously found 115 articles, which were the unique articles found from the databases, matching into the selected keywords, with the screened and finally selected 28 publications. By comparing the results between the channels, it is evident that the topic is mostly in the interest of area-specific journals, whereas conferences and books are present as a minority with a large margin compared to journals. This could indicate that even when the amount of research is scarce, it is most likely high in quality and has been passed a fierce blind peer review process. 
The authors analyzed the given research fields' academic output development for the last 10 years by mapping both the keywords matching 115 articles and the selected 28 studyspecific articles publishing years. The general trend in the 115 keyword matching publications indicates growth in the academic output for the last 3 years (figure 3 ), in the general context of sustainability, waste management, and reporting \& calculation studies.

\begin{tabular}{|c|c|}
\hline YEAR & AMOUNT \\
\hline 2021 & 1 \\
\hline 2020 & 18 \\
\hline 2019 & 17 \\
\hline 2018 & 17 \\
\hline
\end{tabular}

\begin{tabular}{|c|c|}
\hline YEAR & AMOUNT \\
\hline 2017 & 11 \\
\hline 2016 & 7 \\
\hline 2015 & 10 \\
\hline 2014 & 8 \\
\hline
\end{tabular}

\begin{tabular}{|c|c|}
\hline YEAR & AMOUNT \\
\hline 2013 & 8 \\
\hline 2012 & 6 \\
\hline 2011 & 9 \\
\hline 2010 & 5 \\
\hline
\end{tabular}

Fig 3. Amount of keywords matching and base filtering rules matching 115 publications per year.

The data presented in figure 4 compares the yearly scientific output only within the selected 28 publications which shows a bit different story. The reporting and waste management systems related academic studies research area has been shown an increase in publication numbers basically just for the last year or so. This finding certainly indicates the lack of work and clear research gap in the topic area and is well in line with a similar gap found by the previously mentioned studies in the warehouse management systems sector [38].

\begin{tabular}{|c|c|}
\hline YEAR & AMMUNT \\
\hline 2021 & 0 \\
\hline 2020 & 8 \\
\hline 2019 & 3 \\
\hline 2018 & 2 \\
\hline
\end{tabular}

\begin{tabular}{|c|c|}
\hline YEAR & AMOUNT \\
\hline 2017 & 2 \\
\hline 2016 & 1 \\
\hline 2015 & 2 \\
\hline 2014 & 2 \\
\hline
\end{tabular}

\begin{tabular}{|c|c|}
\hline YEAR & AMOUNT \\
\hline 2013 & 1 \\
\hline 2012 & 2 \\
\hline 2011 & 3 \\
\hline 2010 & 2 \\
\hline
\end{tabular}

Fig 4. Publishing years and amounts of publications specific to the research field.

The found 28 studies had 93 unique authors, from which only Christensen contributed more than one publication. He was one of the authors in publications [10] and [16]. Then by analyzing the found publications based on their publication channels, this study found three journals that included more than one article, contributing to the list of found 28 studies. Besides, Table 4 presents the journals and also the article references, published in these journals. All other studies were published in separate channels, in addition to journals, list included some conference proceedings, books, and book sections, without multiple contributing articles.

Table 4. Journals with multiple publications amount the found 28 studies

\begin{tabular}{|l|c|c|}
\hline \multicolumn{1}{|c|}{ JOURNAL } & AMMOUNT OF STUDIES & ARTICLES \\
\hline Waste Management & 3 & {$[2][21][25]$} \\
\hline Journal of Cleaner Production & 2 & {$[11][17]$} \\
\hline Resources, Conservation and Recycling & 2 & {$[8][16]$} \\
\hline
\end{tabular}

To analyze the academics' attention these areas specific 28 publications had received, a reference count analysis was made. This analysis is based on open public data released by Google Scholar [49]. The data is presented in following Table 5. Generally, the picture of these reference counts is quite revealing. All articles (seven of them) with a major amount of citations (25+) were published between the years 2010 and 2016, so they have had time to 
receive attention from their specific audience. One should note, all of these were journal articles. This can be an indication that, even when the publication count is somewhat low, in this sort of topic area right now, at least the quality of the work is appreciated by the science community.

Table 5. Google scholar citation analysis for the 28 studies

\begin{tabular}{|c|c|c|c|c|c|c|c|c|}
\hline ID & Type & Year & Citations & & ID & Type & Year & Citations \\
\hline$[1]$ & Journal Article & 2020 & 3 & & {$[15]$} & Journal Article & 2020 & 0 \\
\hline$[2]$ & Journal Article & 2020 & 1 & & {$[16]$} & Journal Article & 2014 & 62 \\
\hline$[3]$ & Journal Article & 2020 & 2 & & {$[17]$} & Book & 2011 & 1 \\
\hline$[4]$ & Journal Article & 2018 & 5 & & {$[18]$} & Journal Article & 2016 & 59 \\
\hline$[5]$ & Book & 2020 & 0 & & {$[19]$} & Journal Article & 2014 & 102 \\
\hline$[6]$ & Journal Article & 2017 & 12 & & {$[20]$} & Book Section & 2019 & 0 \\
\hline$[7]$ & $\begin{array}{l}\text { Conference } \\
\text { Proceedings }\end{array}$ & 2011 & 1 & & {$[21]$} & Journal Article & 2020 & 5 \\
\hline$[8]$ & Journal Article & 2020 & 5 & & {$[22]$} & $\begin{array}{c}\text { Conference } \\
\text { Proceedings }\end{array}$ & 2020 & 0 \\
\hline$[9]$ & Journal Article & 2012 & 2 & & {$[23]$} & Book & 2012 & 8 \\
\hline$[10]$ & Journal Article & 2010 & 34 & & {$[24]$} & $\begin{array}{c}\text { Conference } \\
\text { Proceedings }\end{array}$ & 2010 & 9 \\
\hline$[11]$ & Journal Article & 2015 & 26 & & {$[25]$} & Journal Article & 2011 & 97 \\
\hline$[12]$ & $\begin{array}{l}\text { Conference } \\
\text { Proceedings }\end{array}$ & 2017 & 1 & & {$[26]$} & Journal Article & 2019 & 0 \\
\hline$[13]$ & Journal Article & 2013 & 28 & & {$[27]$} & $\begin{array}{c}\text { Conference } \\
\text { Proceedings }\end{array}$ & 2019 & 2 \\
\hline$[14]$ & Book & 2015 & 2 & & {$[28]$} & Journal Article & 2018 & 9 \\
\hline
\end{tabular}

Finally, analyzing the average number of pages in the studies, per publishing year, a trend of growth was noticed at the end of the decade (Figure 5). This seems to indicate that the latest studies are growing in amount contributing to this research area and getting more deep and holistic in their views into the topic context.

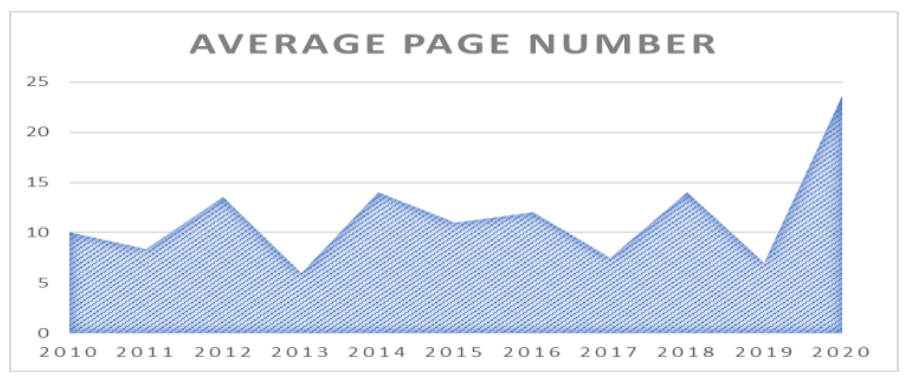

Fig. 5. Avera number of pages in the selected publication.

\section{Conclusion}

Considering the research aim, to map what sort of academic literature this study has available for the matter, the literature review shows a clear lack inside the waste management systems and reporting capabilities crosscutting research area. Only 28 area-specific publications were found from two of the largest research material databases (Web of Science and Scopus). In the findings, almost half (13) from the found topic-specific publications were published in 
the last 3 years (after the year 2017) current academics are sort of pioneers in this multidiscipline research area. Especially, as roughly $30 \%$ of articles (8) were published in 2020 , the findings indicates the research area to be extremely young and in need for additional work.

Given the lack of work in the waste specific data quantifying reporting management systems capabilities, authors suggest producing more systems related research and wide-scale scientific databases mapping studies to specify what exact areas have already started to receive academic contributions and where should be the largest research gaps. Also, big picture fleet-level studies [52-55] could be beneficial, as shown in this preliminary literature review. In this context, the journal articles are highly appreciated by other academics (a lot of references for a large amount of found studies). Most of the studies in this research area are journal articles given a sense of tight community of highly qualified researchers and scientists' contributions to the waste management and reporting context. Besides, three journals of Waste Management, Cleaner Production and Resources, Conservation and Recycling publishing more research than others in the identified 28 publications group. This study suggests research interested in contributing to this topic field to take a closer look at these journals to get a good starting point for deep insight into waste management topics and consider follow-up contributions. It seems only one author (Christensen) has contributed to more than an article, so there could be good academic career paths also available in this topic area.

As for future work, this study would like to suggest more practical studies on the current condition of waste management systems, software solutions offered for waste and sustainability-related operations reporting support, and benchmarking studies to clarify the current situation with the state of the art within different options available in need of tools to report different portions of materials waste streams of:

- $\quad$ private waste processing companies

- $\quad$ sustainability calculations consultation companies

- municipalities

Also, to speed up the software system and solution development efforts, authors would like to suggest trust [50] and knowledge sharing based industry-university collaboration models. For example models like hackathons [44-46], capstone courses [47], front-end innovation process formalization methods [51], plus digital citizen science [55] and community-based monitoring programs [48] as solution options to boost the design of environmentally more sustainable solutions [59].

\section{Acknowledgements}

This research is part of AWARE project, funded by The South-East Finland - Russia CBC 2014-2020 cross-border cooperation programme. The programme is funded by the European Union, the Russian Federation and the Republic of Finland. Authors would also like to express their gratitude for LUT University, for providing the working environment and opportunity to put effort on sustainability focused research and education activities.

\section{References}

1. H. Chen, S. Wang, H. Guo, H. Lin, Y. Zhang, A nationwide assessment of litter on China's beaches using citizen science data.,Environmental Pollution, 258 (2020) http://10.1016/j.envpol.2019.113756

2. L. Rigamonti, S.E. Taelman, S. Huysveld, S. Sfez, K. Ragaert, J. Dewulf, A step forward in quantifying the substitutability of secondary materials in waste management life cycle assessment studies, Waste Manage., 114 (2020) http://doi:10.1016/j.wasman.2020.07.015 
3. F-C. Mihai, Assessment of COVID-19 waste flows during the emergency state in romania and related public health and environmental concerns, Int. J. Environ. Res. Public Health 17, 15 (2020) http://doi:10.3390/ijerph17155439

4. A. Meleko, T. Tesfaye, A. Henok, Assessment of Healthcare Waste Generation Rate and Its Management System in Health Centers of Bench Maji Zon, Ethiopian journal of health sciences 28, 2 (2018) http://10.4314/ejhs.v28i2.4

5. A. Masood, K. Ahmad, Assessment of Municipal Solid Waste Management in Jammu City: Problems, Prospects and Solutions 58 (2020) http://doi:10.1007/978-981-15$\underline{2545-2 \_23}$

6. K. Oduro-Appiah, A. Scheinberg, A. Mensah, A. Afful, H. K. Boadu, N. de Vries, Assessment of the municipal solid waste management system in Accra, Ghana: A "Wasteaware' benchmark indicator approach, Waste Manage Res 35, 11 (2017) http://doi:10.1177/0734242X17727066

7. R.F. Strayer, M.E. Hummerick, J.T. Richards, L.E. McCoy, M.S. Roberts, R.M. Wheeler, Characterization of Volume F trash from four recent STS missions: Weights, categorization, water content. In 41st ICES (2011) http://doi:10.2514/6.2011-5126

8. H. Wu, J. Zuo, H. Yuan, G. Zillante, J. Wang, Cross-regional mobility of construction and demolition waste in Australia: An exploratory study, Resour Conserv Recycl 156 (2020) http://doi:10.1016/j.resconrec.2020.104710

9. M.J. Franchetti, Development of a solid waste prediction, characterization, and modeling tool for the assessment of manufacturing and service waste management systems, Journal of Solid Waste Technology and Management 38, 1 (2012) http://doi:10.5276/JSWTM.2012.38

10. G.S. Bhander, T.H. Christensen, M.Z. Hauschild, EASEWASTE-life cycle modeling capabilities for waste management technologies, International Journal of Life Cycle Assessment 15, 4 (2010) http://doi:10.1007/s11367-010-0156-7

11. L. Rigamonti, S. Ferreira, M. Grosso, R.C. Marques, Economic-financial analysis of the Italian packaging waste management system from a local authority's perspective, J Clean Prod 87 (2015) http://doi:10.1016/j.jclepro.2014.10.069

12. A. Bellini, A. Bonoli, Energy balance of waste management systems: A case study, In 2017 IEEE IEEM Conference (2017), https://doi:10.1109/IEEM.2017.8290142

13. R. Kumari, K. Srivastava, A. Wakhlu, A. Singh, Establishing biomedical waste management system in Medical University of India - A successful practical approach, Clin Epidemiol Glob Health 1, 3 (2013) https://doi:10.1016/j.cegh.2012.11.004

14. M. Yekkalar, S. Panahi, M. Nikravan, Evaluation of Current Laboratory Waste Management: A Step Towards Green Campus at Amirkabir University of Technology, (Filho WL, Muthu N, Edwin G, Sima M, eds.). Springer Int Publishing Ag; (2015)

15. C. Liu, T.T. Nguyen, Evaluation of household food waste generation in hanoi and policy implications towards SDGs target 12.3, Sustainability 12, 16 (2020) https://10.3390/su12166565

16. L.K. Brogaard, A. Damgaard, M.B. Jensen, M. Barlaz, T.H. Christensen, Evaluation of life cycle inventory data for recycling systems, Resources, Conservation and Recycling 87. (2014) https://10.1016/j.resconrec.2014.03.011

17. L. Zhu, Z. Cui, J. Zhou, In Advanced Materials Research 156 (2011) https://doi:10.4028/www.scientific.net/AMR.156-157.808

18. A.B. Saraiva Schott, H. Wenzel, J. la C. Jansen, Identification of decisive factors for greenhouse gas emissions in comparative life cycle assessments of food waste 
management - an analytical review, J Clean Prod 119 (2016)

https://doi:10.1016/j.jclepro.2016.01.079

19. A.U. Zaman, Identification of key assessment indicators of the zero waste management systems, Ecological Indicators 36 (2014) https://10.1016/j.ecolind.2013.09.024

20. I.L. Manzhurov, K. Antonov, M. Kit, D.B. Berg, D. Denisov. Information System for Decision Support in Waste Management in the Arctic Region of Russia. In AIP Conference Proceedings 2116 (2019) https://doi:10.1063/1.5114447

21. H.L. Vu, K.T.W. Ng, B. Fallah, A. Richter, G. Kabir, Interactions of residential waste composition and collection truck compartment design on GIS route optimization, Waste Management 102 (2020) https://doi:10.1016/j.wasman.2019.11.028

22. M.N. Khan, F. Naseer IoT based university garbage monitoring system for healthy environment for students, In 2020 IEEE 14th International Conference on Semantic Computing (ICSC) (2020) https://doi:10.1109/ICSC.2020.00071

23. J. Soukopova, J. Kalina, Mathematical Model of Economics of Municipal Waste Management, (Ramik J, Stavarek D, eds.). Silesian Univ Opava, School Business Administration Karvina (2012)

24. H. Jiri, S. Jana, Modelling integrated Waste Management System of the Czech Republic, In Proceedings of the 14th WSEAS International Conference on Latest Trends on Systems 1 (2010)

25. E. Friedrich, C. Trois, Quantification of greenhouse gas emissions from waste management processes for municipalities - A comparative review focusing on Africa, Waste Management 31, 7 (2011) https://doi:10.1016/j.wasman.2011.02.028

26. M-AM Uche, J. Whalley, L. Chile, P. Salli, Shaping and delivering tomorrow's sustainable municipal solid waste management system: Proposal for a structured data management infrastructure, Int J Environ Waste Manag, 24, 4 (2019) https://doi:10.1504/IJEWM.2019.103646

27. G.M. Monzambe, K. Mpofu, I.A. Daniyan, Statistical analysis of determinant factors and framework development for the optimal and sustainable design of municipal solid waste management systems in the context of industry 4.0, Procedia CIRP. 84 (2019) https://doi:10.1016/j.procir.2019.04.182

28. N. Tsydenova, A.V. Morillas, A.A.C. Salas, Sustainability assessment of waste management system for mexico city (Mexico) - based on analytic hierarchy process, Recycling 3, 3 (2018) https://doi:10.3390/recycling3030045

29. P.C. Stern, Toward a Coherent Theory of Environmentally Significant Behavior, JSI, 56, 3 (2000), pp. 407-424, https://doi.org/10.1111/0022-4537.00175

30. A. Menon, A. Menon, Enviropreneurial marketing strategy: The emergence of corporate environmentalism as market strategy, Journal of Marketing, 61, 1 (1997), pp. 51-67, https://doi.org/10.2307/1252189

31. J.L., Hardcastle. Nike, Starbucks: Climate Change Policy Is 'Economic Opportunity,', Environmental Leader, April 11, (2013)

32. K. Ejsmont, B. Gladysz, A. Kluczek, Impact of Industry 4.0 on SustainabilityBibliometric Literature Review, Sustainability, 12, 14 (2020), paper id: 5650, https://doi.org/10.3390/su12145650

33. B. Jovanovski, D. Seykova, A. Boshnyaku, C. Fischer, The Impact of Industry 4.0 on the Competitiveness of SMEs, in IV International Scientific Conference - Industry 4.0, pp. 130-135, 24-27 June 2019, Burgas, Bulgaria 
34. S. Doherty, S. Hoyle, Supply chain decarbonization: role of transport and logistics in reducing supply chain carbon emissions, World Economic Forum report, (2009)

35. D. Minashkina, A. Happonen, Decarbonizing warehousing activities through digitalization and automatization with WMS integration for sustainability supporting operations, in E3S Web Conf (ICEPP 2019), Vol. 158, (2020), pp. 1-7, https://doi.org/10.1051/e3sconf/202015803002

36. D. Minashkina, A. Happonen, Operations automatization and digitalization - a research and innovation collaboration in physical warehousing, AS/RS and 3PL logistics context, in LUT Research Reports series report 86, ISBN 978-952-335-293-3, ISSN 2243-3376, (2018), p. 66

37. D. Minashkina, A. Happonen, A development of the warehouse management system selection framework as academic-industrial collaboration work with sustainability considerations, in AIP Conference Proceedings, 2233, 1 (2020), pp. 1-12, https://doi.org/10.1063/5.0001884

38. D. Minashkina, A. Happonen, Systematic literature review and research gap issues on third party logistics operators selecting WMS for efficient operations for customers, International Journal of Supply Chain and Inventory Management, 3, 2 (2020), pp. 142-166, https://doi.org/10.1504/IJSCIM.2020.107282

39. D. Budgen, P. Brereton, Performing systematic literature reviews in software engineering, in Proceedings of the 28th international conference on Software engineering, May 2006, pp. 1051-1052, https://doi.org/10.1145/1134285.1134500

40. B. Kitchenham, S. Charters, Guidelines for Performing Systematic Literature Reviews in Software Engineering, EBSE Technical Report, (2007), pp. 1-65

41. A. Allesch, P.H. Brunner, Assessment methods for solid waste management: A literature review, WM\&R: The Journal for a Sustainable Circular Economy, 32, 6 (2014), pp. 461-473, https://doi.org/10.1177/0734242X14535653

42. P.S. Dawane, S.M. Gawande, Solid waste management- A review, International journal of current research, 7, 5 (2015), pp. 16019-16024

43. F.T.F. Moraes, A.T.T. Gonçalves, J.P. Lima, R. da Silva Lima, An assessment tool for municipal construction waste management in Brazilian municipalities, Waste Management \& Research: The Journal for a Sustainable Circular Economy, 38, 7 (2020), pp. 762-772, https://doi.org/10.1177/0734242X20906886

44. J. Porras, J. Khakurel, J. Ikonen, A. Happonen, A. Knutas, A. Herala, O. Drögehorn, Hackathons in software engineering education - lessons learned from a decade of events, In International Conference on Software Engineering 2018 (ICSE), pp. 40-47, Gothenburg, Sweden (2018, https://doi.org/10.1145/3194779.3194783

45. J. Porras, A. Knutas, J. Ikonen, A. Happonen, J. Khakurel, A. Herala, Code camps and hackathons in education - literature review and lessons learned, In proceedings of the 52nd Hawaii International Conference on System Sciences (HICSS 2019), pp. 77507759, Hawaii, USA (2018), https://doi.org/10.24251/HICSS.2019.933

46. A. Happonen, D. Minashkina, A. Nolte, M.A. Medina Angarita, Hackathons as a Company - University Collaboration Tool to Boost Circularity Innovations and Digitalization Enhanced Sustainability, in AIP Conference Proceedings, Vol. 2233, Iss. 1, p. 1-11, (2020), https://doi.org/10.1063/5.0001883

47. M. Palacin-Silva, J. Khakurel, A. Happonen, T. Hynninen, J. Porras, Infusing Design Thinking Into a Software Engineering Capstone Course, In the 30th IEEE Conference on Software Engineering Education and Training (CSEE\&T), pp. 1-10, Savannah, Georgia, USA (2017) http://doi.org/10.1109/CSEET.2017.41 
48. V. Palacin, S. Ginnane, M.A. Ferrario, A. Happonen, A. Wolff, S. Piutunen, N. Kupiainen, SENSEI: Harnessing Community Wisdom for Local Environmental Monitoring in Finland, in CHI Conference on Human Factors in Computing Systems, pp. 1-8, Glagsgow, Scotland UK (2019), https://doi.org/10.1145/3290607.3299047

49. A-W.K. Harzing, R. van der Wal, Google Scholar as a new source for citation analysis, ESEP, 8, 1 (2008), pp. 61-73, https://doi.org/10.3354/esep00076

50. A. Happonen, V. Siljander, Gainsharing in Logistics Outsourcing: Trust leads to Success in the Digital Era, International Journal of Collaborative Enterprise, 6, 2 (2020) pp. 150-175, https://doi.org/10.1504/IJCENT.2020.10032309

51. E. Salmela, C. Santos, A. Happonen, Formalization of Front End Innovation in Supply Network Collaboration, International Journal of Innovation and Regional Development, 5, 1 (2013), pp. 91-111, https://doi.org/10.1504/IJIRD.2013.052510

52. S-K., Kinnunen, A. Happonen, S. Marttonen-Arola, T. Kärri, Traditional and extended fleets in literature and practice: definition and untapped potential, International Journal of Strategic Engineering Asset Management, 3, 3 (2019), pp. 239-261, https://doi.org/10.1504/IJSEAM.2019.108467

53. H. Kortelainen, A. Happonen, S-K- Kinnunen, Fleet Service Generation - Challenges in Corporate Asset Management, Lecture Notes in Mechanical Engineering, Springer, pp. 373-380, (2016), https://doi.org/10.1007/978-3-319-27064-7_35

54. H. Kortelainen, A. Happonen, J. Hanski, From asset provider to knowledge company transformation in the digital era, In Lecture Notes in Mechanical Engineering, pp. 333341, (2019), https://doi.org/10.1007/978-3-319-95711-1_33

55. V. Palacin, S. Gilbert, S. Orchard, A. Eaton, M.A. Ferrario, A. Happonen, Drivers of Participation in Digital Citizen Science: Case Studies on Järviwiki and Safecast, Citizen Science: Theory and Practice, 5, 1 (2020) pp. 1-20, http://doi.org/10.5334/cstp.290

56. E. Salmela, A. Happonen, Role of Logistics Service Provider in Supply Chain Between Manufacturer and Subcontractor, ISL 2009 - Global supply chains and inter-firm networks, Istanbul, Turkey, ISBN 978-0-85358-220-5, (2009), pp. 531-537

57. E. Salmela, A. Happonen, J. Huiskonen, New Concepts for Demand-Supply Chain Synchronization, International Journal of Manufacturing Research, 7, 2 (2012), pp. 148-164, https://doi.org/10.1504/IJMR.2012.046800

58. E. Salmela, A. Happonen, Synchronization of Demand and Supply in a Supply Chain Manufacturing Industrial Products, 16th International Annual EurOMA Conference, Göteborg, Sweden, p. 9, (2009)

59. T. Eskelinen, T. Räsänen, U. Santti, A. Happonen, M. Kajanus, Designing a Business Model for Environmental Monitoring Services Using Fast MCDS Innovation Support Tools, Technology Innovation Management Review, 7, 11 (2017), pp. 36-46, http://doi.org/10.22215/timreview/1119 